\title{
Analisis Pelaksanaan Tindak Lanjut Hasil Pemeriksaan BPK RI atas Laporan Keuangan Pemerintah Daerah di Kabupaten Kepulauan Talaud
}

\author{
SISILIA AMELIA ESSING ${ }^{1}$, DAVID P. E. SAERANG ${ }^{2}$, LINDA LAMBEY ${ }^{3}$ \\ ${ }^{1,2,3}$ Program Magister Akutansi, Fakultas Ekonomi dan Bisnis Universitas Sam Ratulangi \\ email : sisilia.essing@gmail.com ${ }^{1}$,d_saerang@unsrat.ac.id ${ }^{2}$, lindalambey@yahoo.com ${ }^{3}$
}

\begin{abstract}
Follow up audit results by State Audit Agency or Badan Pemeriksa Keuangan (BPK) are intended to fulfill its obligations as recommended in Audit Report. The completion of follow up audit results has been slightly increased. The percentage is higher than average. However, it is still below the minimal standard determined by BPK. Time completion is ineffectively conducted. This study is a qualitative research and a case study. This research was conducted in Local Government of Talaud Islands Regency. Data consists of primary and secondar data. Primary data were collected with indepth interviews. On the other hard, secondary data were employed by document analysis. Interviews were transcribed into data transcriptions, analysed, coded, and categorized into themes. Content analysis was used to analyse the data. Resuls indicate that the quality of human resources in this team faces obstacles: (1) The lack of understanding in responding or following up the audit recommendations; (2) The insufficient number of staff involving in executing the follow up audit results; and (3) The follow up process is not fully being implemented. The process must be in accordance to Standard Operating Procedure (SOP) of follow up audit results by BPK. Moreover, this SOP is not yet publicized among the team.
\end{abstract}

Keywords : Follow-up audit results, Human Resources, and Standard Operating Procedure.

Abstrak. Tindak lanjut hasil pemeriksaan Badan Pemeriksa Keuangan adalah tindak lanjut yang dilakukan oleh pemerintah daerah untuk memenuhi kewajiban seperti yang dituangkan dalam rekomendasi Laporan Hasil Pemeriksaan Badan Pemeriksa Keuangan. Penyelesaian tindak lanjut mengalami peningkatan walaupun sangat kecil. Persentasi saat ini berada diatas rata-rata, namun belum mencapai standar minimal dari Badan Pemeriksa Keuangan. Waktu penyelesaian tindak lanjut tidak efektif dilaksanakan. Penelitian ini merupakan penelitian kualitatif dengan jenis penelitian studi kasus. Lokasi penelitian di Pemerintah Daerah Kabupaten Kepulauan Talaud. Sumber data yang digunakan dalam penelitian ini adalah data primer dan data sekunder. Data primer diperoleh dari wawancara mendalam terhadap responden individual. Data sekunder diperoleh dari studi dokumentasi. Hasil wawancara di-transcribe menjadi transkrip data, kemudian dianalisis, diberi kode, dan dikategorikan ke dalam tema. Analisis data menggunakan analisis isi. Hasil penelitian menunjukkan bahwa kualitas Sumber Daya Manusia dari tim teknis cukup memadai. Namun masih ada hambatan bagi tim teknis : (1) kurangnya pemahaman tentang cara menindaklanjuti rekomendasi hasil pemeriksaan; (2) jumlah personil yang dilibatkan dalam pelaksanaan tindak lanjut masih kurang; (3) proses tindak lanjut belum sepenuhnya dilakukan berdasarkan prosedur yang tertuang dalam Standar Operasional Prosedur Tindak Lanjut Hasil Pemeriksaan Badan Pemeriksa Keuangan Republik Indonesia. Selain itu Standar Operasional Prosedur yang telah dibuat belum dipublikasikan kepada tim .

Kata kunci: Tindak lanjut hasil pemeriksaan, Sumber Daya Manusia, dan Standar Operasional Prosedur. 


\section{Pendahuluan}

Pelaksanaan pemeriksaan (audit) atas laporan keuangan pemerintah daerah (LKPD) dilakukan oleh pihak eksternal audit, yaitu Badan Pemeriksa Keuangan Republik Indonesia (BPK RI) yang merupakan lembaga negara yang bertugas untuk memeriksa pengelolaan dan tanggung jawab keuangan negara. Pemeriksaan atas laporan keuangan bertujuan untuk memberikan keyakinan yang memadai (reasonable assurance) bahwa laporan keuangan telah disajikan secara wajar dalam semua hal yang material, sesuai dengan prinsip akuntansi yang berlaku umum di Indonesia atau basis akuntansi komprehensif lainnya (IHPS I, 2016).

LHP BPK atas pemeriksaan keuangan pemerintah daerah memuat temuan pemeriksaan. Setiap temuan dapat terdiri atas satu atau lebih permasalahan, yaitu berupa kelemahan Sistem Pengendalian Intern (SPI) dan ketidakpatuhan terhadap ketentuan peraturan perundang-undangan (IHPS I, 2016).

Perbaikan atas temuan pemeriksaan dalam LHP disampaikan dalam bentuk rekomendasi. Setiap satuan/unit kerja (sebagai pihak auditi) mempunyai kewajiban untuk merespon rekomendasi tersebut dalam bentuk tindak lanjut sebagaimana diatur dalam pasal 3, 4, dan 5 Peraturan BPK RI Nomor 2 Tahun 2010.

Jawaban atau penjelasan tentang tindak lanjut rekomendasi disampaikan oleh pejabat yang diperiksa dan/atau pejabat yang bertanggung jawab kepada BPK. Selanjutnya BPK menelaah jawaban tersebut untuk menentukan apakah tindak lanjut rekomendasi telah dilakukan sesuai dengan rekomendasi BPK. Hasil penelaahan diklasifikasikan dalam 4 (empat) status, yaitu : (1) tindak lanjut telah sesuai dengan rekomendasi; (2) tindak lanjut belum sesuai dengan rekomendasi; (3) rekomendasi belum ditindaklanjuti; dan (4) rekomendasi tidak dapat ditindaklanjuti (IHPS I, 2016).

Inpektorat Kabupaten Kepulauan Talaud sebagai Aparat Pengawasan Internal Pemerintah (APIP) juga merupakan bagian dari auditi BPK dan sebagai tim pendamping dalam pemeriksaan, sekaligus tim pelaksana TLHP berusaha secara maksimal sesuai tugas pokok dan fungsinya untuk mewujudkan pengelolaan keuangan yang transparan dan akuntabel.

Keberhasilan dari peran dan tugas yang diemban oleh Inspektorat (internal auditor) salah satunya ditunjukkan dengan adanya kecenderungan berkurangnya jumlah temuan audit. Banyaknya temuan audit yang belum ditindaklanjuti merupakan tanggung jawab bagi auditi untuk penyelesaiannya dengan tetap dimonitor oleh auditor (Hartono, 2006).

Menurut Kaplan dan Norton (1996) untuk mencapai kinerja yang handal ada 3 (tiga) faktor yang perlu diperhatikan yaitu, kemampuan pegawai (employee capability), kemampuan sistem informasi (information system capability), motivasi pemberdayaan dan keserasian individu (motivation, empowerment, and alignment). Faktor-faktor tersebut digunakan untuk memperkecil kesenjangan dalam bentuk peningkatan kemampuan sistem dan teknologi informasi, meluruskan prosedur, dan perbaikan rutinitas.

Kinerja Inspektorat ditentukan oleh berbagai faktor untuk dapat mencapai kinerja yang handal. Dalam Modul Manajemen Fungsi Audit Internal Sektor Publik (2007) bahwa untuk mewujudkan peran Inspektorat, orang-orang di lingkungan Inspektorat wajib mempunyai kompetensi yang tinggi dalam bidangnya. Oleh karena itu, untuk merealisasikan kepentingan tersebut, beberapa faktor yang perlu diperhatikan antara lain komitmen yang tegas dan kontinyu dari pimpinan, peningkatan kemampuan teknis dan profesional, penyempurnaan kebijakan, sistem, dan prosedur, peningkatan komunikasi dan koordinasi tindak lanjut hasil pemeriksaan, serta monitoring dan evaluasi atas penyelenggaraan pemerintahan daerah.

Penyelesaian TLHP yang merupakan perwujudan kinerja Inspektorat tercermin dalam data rekonsiliasi pemantauan tindak lanjut tahun 2005 sampai dengan semester II bulan Desember TA 2015. Hasil pemantauan menunjukkan bahwa tindak lanjut yang dilaksanakan 
sesuai dengan rekomendasi sebanyak 356 rekomendasi atau 61,6 \% dari 578 rekomendasi, tindak lanjut belum sesuai rekomendasi sebanyak 185 rekomendasi atau sebesar $32.00 \%$, rekomendasi belum ditindaklanjuti sebanyak 37 rekomendasi atau sebesar 6,4 \%, serta rekomendasi yang tidak dapat ditindaklanjuti sebanyak 0 rekomendasi atau sebesar $0 \%$.

Upaya tindak lanjut belum maksimal dilakukan, terlihat masih adanya rekomendasi yang belum ditindaklanjuti, tindak lanjut belum sesuai rekomendasi, dan keterlambatan penyelesaian tindak lanjut (tidak tepat waktu). Respon pejabat yang diperiksa atau pejabat yang bertanggung jawab pada BPK, dalam hal tindak lanjut masih kurang. Dari gambaran tersebut diatas dapat dikatakan belum optimalnya dukungan/keterlibatan semua pihak dalam pelaksanaan TLHP sebagai wujud akuntabilitas.

Belum optimalnya pelaksanaan TLHP, seharusnya tidak terjadi karena sudah ada Standar Operasional Prosedur (SOP) TLHP BPK RI yang dikeluarkan oleh Bupati Kepulauan Talaud. Tim pelaksana SOP yang dibentuk seharusnya segera menindaklanjuti kelemahankelemahan yang terjadi. Hal inilah yang membuat peneliti tertarik untuk menganalisis bagaimana kinerja tim pelaksana SOP TLHP BPK RI yang merupakan bagian tugas dan fungsi dari Inspektorat, dan apa saja faktor yang menghambat keberhasilan pelaksanaan tindak lanjut di Kabupaten Kepulauan Talaud.

Tujuan yang ingin dicapai dalam penelitian ini adalah untuk menganalisis pelaksanaan TLHP BPK RI dan prosedur pelaksanaan tindak lanjut, menganalisis faktor-faktor yang menghambat keberhasilan, serta menganalisis upaya yang akan dilakukan untuk meningkatkan pelaksanaan TLHP BPK RI di Kabupaten Kepulauan Talaud.

Kerangka pikir yang dibangun dalam penelitian kualitatif ini adalah pelaksanaan tindak lanjut terhadap rekomendasi hasil pemeriksaan BPK RI dilaksanakan sesuai Standar Operasional Prosedur (SOP) TLHP BPK RI yang mengacu pada Peraturan BPK Nomor 2 Tahun 2010 tentang Pemantauan Tindak Lanjut Hasil Pemeriksaan BPK.

Penyelesaian rekomendasi dipengaruhi oleh berbagai faktor yang dapat menghambat dan menentukan keberhasilan TLHP. Faktor-faktor tersebut merupakan rangkaian proses pelaksanaan kegiatan yang saling berhubungan, mempengaruhi, dan dipengaruhi membentuk suatu sistem yang terdiri dari input, proses, output (Usman, 2013).

Dengan memasukan faktor SDM, motivasi dan kepuasan kerja, komitmen, kepemimpinan, pengkomunikasian dan koordinasi, Standar Operasional Prosedur (SOP), serta evaluasi dan monitoring kedalam proses tindak lanjut, diharapkan dapat menjawab permasalahan terjadinya ketidaksesuaian rekomendasi, belum ditindaklanjuti temuan hasil pemeriksaan, dan keterlambatan penyelesaian TLHP BPK RI di Kabupaten Kepulauan Talaud.

\section{Metode Penelitian}

Penelitian ini merupakan penelitian kualitatif dan jenis penelitiannya adalah studi kasus (case study). Metode ini digunakan untuk mengetahui dan menganalisis secara mendalam penyebab terjadinya permasalahan tersebut serta menganalisis faktor-faktor apa saja yang menghambat keberhasilan TLHP BPK RI, serta upaya-upaya yang akan dilakukan.

Teknik pengumpulan data yang digunakan meliputi wawancara mendalam (in-depth interview), dan studi dokumentasi. Selanjutnya data yang telah terkumpul diolah dengan prosedur, membuat transkrip wawancara (interviews transcriptions), melakukan analisis data, melakukan validasi data, dan mengambil kesimpulan dari hasil penelitian.

Analisis data menggunakan analisis isi (content analysis). Menurut Bungin (2007) analisis isi (content analysis) didahului dengan melakukan coding kemudian, dilakukan klasifikasi terhadap coding, selanjutnya dikategorikan kemudian dimasukkan ke dalam tema.

Pengujian keabsahan data dilakukan dengan menyandingkan antara sumber data dengan data lainnya, yaitu data yang diperoleh dari hasil wawancara dengan studi 
dokumentasi. Uji keabsahan data yang digunakan dalam penelitian ini adalah credibility, dan dependability.

Uji kredibilitas data atau kepercayaan terhadap data hasil penelitian antara lain dilakukan dengan triangulasi (triangulation). Triangulasi yang dapat digunakan diantaranya, triangulasi sumber data dan triangulasi teknik pengumpulan data (Sugiyono, 2015).

\section{Hasil dan Pembahasan}

Analisis dilakukan berdasarkan pada kerangka konsep dan tujuan penelitian, yaitu menganalisis prosedur pelaksanaan TLHP BPK RI di Kabupaten Kepulauan Talaud, SDM, motivasi dan kepuasan kerja, komitmen, kepemimpinan, pengkomunikasi-an dan koordinasi, Standar Operasional Prosedur (SOP), monitoring dan evaluasi, serta faktor penghambat lainnya. Hasil penelitian yang dilakukan di lapangan disajikan secara narasi.

\section{Tindak Lanjut Hasil Pemeriksaan}

Pertanyaan pandangan tentang pelaksanaan TLHP BPK RI di Kabupaten Kepulauan Talaud yang disampaikan kepada semua informan untuk mendapatkan informasi pelaksanaan TLHP BPK RI dan prosedur tindak lanjut. Hasil wawancara mendalam semua informan menjelaskan tentang manfaat TLHP BPK RI, peningkatan atau progress TLHP, waktu penyelesaian TLHP, prosedur pelaksanaan TLHP, hambatan pelaksanaan TLHP, dan upaya yang akan dilakukan untuk meningkatkan TLHP BPK RI di Kabupaten Kepulauan Talaud.

Menurut beberapa pendapat dari hasil wawancara tentang manfaat TLHP dapat disimpulkan bahwa pelaksanaan TLHP BPK RI adalah bagian yang sangat penting dalam mendorong terciptanya pemerintahan yang bersih dan untuk perbaikan atas penyelenggaraan pemerintahan bahkan pengelolaan keuangan daerah di Kabupaten Kepulauan Talaud. TLHP adalah kewajiban pemerintah daerah menindak lanjuti sesuai dengan ketentuan yang berlaku atas seluruh hasil pemeriksaan BPK. TLHP ini bermanfaat untuk memperbaiki, memberikan pendidikan patuh terhadap ketentuan-ketentuan yang berlaku, serta dapat menyelamatkan auditan atau yang bersangkutan dari jerat hukum. TLHP juga dapat menambah pendapatan atas pengembalian kerugian daerah yang diakibatkan dan berpengaruh terhadap pemberian opini atas LKPD untuk mencapai WTP.

Menurut Akmal (2006) TLHP sebagai suatu proses untuk menentukan kecukupan, keefektifan dan ketepatan waktu tindakan-tindakan koreksi yang dilakukan oleh manajemen terhadap rekomendasi dari temuan pemeriksaan yang dilaporkan. Termasuk temuantemuan yang berkaitan yang diperoleh oleh pemeriksa baik intern maupun ekstern.

Hasil wawancara mendalam tentang progress TLHP bahwa dalam dua tahun terakhir ini terus mengalami peningkatan, namun belum sepenuhnya terselesaikan untuk tindak lanjut yang bersifat kerugian. Persentase saat ini berada di atas $60 \%$ atau sudah berada diatas rata-rata, namun belum mencapai standar minimal dari BPK, yaitu $75 \%$. Peningkatan TLHP ini juga disertai dengan peningkatan opini Kabupaten Kepulauan Talaud dari disclaimer, menjadi TW dan dua tahun terakhir ini WDP. Salah satu titik poinnya karena TLHP BPK itu sudah mencapai target minimal yang ditetapkan BPK yaitu $60 \%$ dari temuan yang diberikan.

Berdasarkan data pemantauan TLHP tahun 2005 s.d semester II bulan Desember tahun 2016 bahwa tindak lanjut yang dilaksanakan sesuai dengan rekomendasi sebanyak 366 rekomendasi atau 61,72 \% dari 593 rekomendasi. Jika dilihat progress TLHP tahun 2015 sebanyak 356 rekomendasi atau 61,6 \% dari 578 rekomendasi ini mengalami peningkatan walaupun sangat kecil yaitu 0,12\%. Peningkatan ini terjadi atas rekomendasi tahun 2015 sebanyak 1 rekomendasi tindak lanjut yang telah ditindaklanjuti sesuai dengan rekomendasi. Hasil pemantauan tersebut menggambarkan penyelesaian tindak lanjut untuk tahun 2005 sampai 2014 mengalami kesulitan. 
Pendapat tentang waktu penyelesaian tindak lanjut dari hasil wawancara menjelaskan kewajiban waktu yang diberikan oleh BPK adalah 60 (enam puluh) hari sejak tanggal diterimanya LHP. Setelah 60 hari temuan tersebut sudah dapat berindikasi pidana maka harus segera diserahkan ke Aparat Penegak Hukum (APH).

Prosedur untuk penjadwalan melaksanakan tindak lanjut harus didasarkan pada risiko dan kerugian yang terkait juga tingkat kesulitan dan perlunya ketepatan waktu dalam penerapan tindakan korektif (Tugiman, 1997).

Peraturan BPK RI Nomor 02 Tahun 2010, menyatakan bahwa pejabat wajib menindaklanjuti rekomendasi dalam hasil pemeriksaan setelah hasil pemeriksaan diterima dengan berupa jawaban atau penjelasan atas pelaksanaan tindak lanjut yang wajib disampaikan kepada BPK paling lambat 60 (enam puluh) hari setelah laporan hasil pemeriksaan diterima dengan dilampiri dokumen bukti pendukung. Kenyataan yang terjadi pada pemerintah Kabupaten Kepulauan Talaud penyelesaian tindak lanjut tidak efektif dalam 60 hari yang ditentukan.

Berdasarkan hasil wawancara mendalam informan menyebutkan tahapan-tahapan dalam prosedur tindak lanjut adalah sebagai berikut :

1. Menerima LHP yang disampaikan secara resmi oleh BPK.

2. Membuat rencana aksi (action plan).

3. Penggandaan LHP.

4. Mengundang rapat dan menyampaikan temuan kepada SKPD yang terkait temuan BPK.

5. Menginventarisasi temuan.

6. Menyurat ke SKPD terkait temuan BPK.

7. Melakukan rapat pembahasan /pemukhtahiran data.

8. Rekapitulasi hasil tindak lanjut sekaligus membuat daftar TLHP.

9. Melakukan rekonsiliasi.

10. Membuat Berita Acara penyerahan.

11. Menyampaikan tindak lanjut ke BPK.

Dari hasil penelitian diperoleh berbagai hambatan dalam pelaksanaan TLHP BPK RI. Hambatan-hambatan ini mengakibatkan permasalahan tindak lanjut belum sesuai rekomendasi, rekomendasi yang belum ditindaklanjuti, rekomendasi yang sulit ditindaklanjuti, dan keterlambatan penyelesaian tindak lanjut.

Hambatan atas permasalahan tindak lanjut belum sesuai rekomendasi adalah :

1. Tindak lanjut belum secara tuntas dan nyata hanya sebagian-sebagian secara menyicil atau bertahap.

2. Ketidakpahaman dan ketidakmampuan dari SKPD untuk menindaklanjuti rekomendasi BPK.

3. Pegawai yang menangani tindak lanjut sudah tidak lagi menangani tindak lanjut.

4. Kurangnya keseriusan SKPD dalam menangani tindak lanjut.

5. Rekomendasi temuan yang kurang jelas dan tidak mencantumkan nilai.

Hambatan atas rekomendasi yang belum ditindaklanjuti adalah :

1. Pada tahun 2005 sampai 2012 orientasi dan prioritas tentang tindak lanjut tidak penuh.

2. Penanggung jawab temuan yang sudah pensiun mengalami kesulitan penyetoran temuan kerugian.

3. Ketidakmampuan yang bersangkutan dalam melunasi temuan kerugian;

4. Tempat atau alamat yang jauh.

Selain itu juga dari hasil wawancara diperoleh bahwa ada temuan-temuan yang sulit ditindaklanjuti. Hambatan-hambatan atas permasalahan tersebut adalah:

1. Rekomendasi yang tidak relevan dengan bukti yang terjadi, yaitu sisa kas di SKPD pada tahun 2007 sampai 2008. 
2. Yang bersangkutan meninggal dunia.

3. Perusahaan-perusahaan yang terkait temuan sudah tidak diketahui keberadaannya.

4. Pegawai yang terkait temuan sudah pindah alamat atau pindah tugas.

5. Dokumen-dokumen yang terkait tindak lanjut sulit ditemukan atau sudah hilang.

Kemudian hambatan atas keterlambatan penyelesaian tindak lanjut adalah:

1. Kesadaran dari orang yang melakukan kesalahan masih sangat rendah.

2. Punishment dari pimpinan masih sangat lemah.

3. SDM di SKPD yang kurang mampu memerlukan waktu yang lama untuk penyelesaian tindak lanjut.

4. Pembayaran yang menyicil melewati waktu yang ditentukan.

5. Penanggung jawab temuan terlambat bahkan hampir tidak menyampaikan tindak lanjut.

6. Pejabat yang kurang memahami maksud dan tujuan TLHP BPK RI.

7. Pejabat yang kurang proaktif dengan tim teknis TLHP BPK RI.

8. Perusahaan-perusahaan terkait temuan atas belanja modal, kontraktornya bukan dari Talaud, sehingga mengalami keterlambatan penyelesaian tindak lanjut.

9. Kurangnya kooperatif dari penanggung jawab temuan.

10. Penanggung jawab temuan tidak berada di lokasi.

Disamping itu juga dari hasil wawancara mendalam diketahui faktor-faktor yang menghambat keberhasilan tindak lanjut di Kabupaten Kepulauan Talaud selain hambatanhambatan yang diuraikan sebelumnya. Faktor penghambat lainnya adalah :

1. Terbatasnya anggaran atau pembiayaan kegiatan tindak lanjut.

2. Tidak adanya tunjangan tim teknis SOP TLHP.

3. Toleransi dari pimpinan masih tinggi.

4. Kesalahpahaman persepsi antara pemeriksa dengan entitas.

5. Kelalaian penanggung jawab temuan.

6. Kelalaian tim teknis SOP atas beberapa SKTJM yang kadaluarsa.

7. Kurangnya komitmen pimpinan SKPD.

8. Kurangnya peran dari pejabat yang dibawahnya.

9. Sikap acuh tak acuh dari penanggung jawab temuan.

10. Anggota DPRD yang purna bakti.

Adapun upaya-upaya yang akan dilakukan untuk meningkatkan tindak lanjut. Upayaupaya tersebut menurut informan adalah upaya dari tim teknis Inspektorat maupun upaya dari pemerintah daerah.

Upaya-upaya yang akan dilakukan tim teknis Inspektorat antara lain :

1. Menghimbau kepada yang bersangkutan untuk segera menindaklanjuti temuan.

2. Semua PNS yang pindah dari Kabupaten Kepulauan Talaud mendapatkan rekomendasi dari Inspektorat.

3. Mengundang SKPD terkait dalam hal penegasan temuan kerugian.

4. Memonitor sejauh mana pelaksanaan tindak lanjut yang dilakukan SKPD terkait temuan.

5. Memantau dan memberikan jalan keluar serta membantu yang bersangkutan untuk penyelesaian TLHP.

6. Melakukan pendekatan dengan SKPD, mencari informasi nama dan alamat yang bersangkutan.

7. Melakukan pembinaan terhadap SKPD yang terkait dengan temuan BPK RI.

8. Melakukan pertemuan dengan kepala SKPD.

9. Mengingatkan baik secara lisan maupun tertulis.

Selain itu juga ada upaya dari pemerintah daerah, yaitu : 
1. Dalam penentuan pejabat akan ditempati oleh pejabat PNS yang tidak mempunyai TGR, dan bagi pihak ketiga yang akan mendapatkan pekerjaan adalah yang tidak terbelit TGR atau temuan-temuan dari BPK.

2. Mengefektifkan Majelis TPTGR.

3. Merespon TLHP BPK RI dengan melakukan rapat-rapat evaluasi yang dipimpin langsung oleh Bupati.

4. Untuk temuan yang sulit ditindaklanjuti sudah diusulkan kepada BPK RI Pusat untuk dimasukkan ke dalam kategori temuan yang tidak dapat ditindaklanjuti.

\section{Sumber Daya Manusia}

Kualitas SDM dari tim teknis TLHP BPK RI dilihat dari pengetahuan, keterampilan, kemampuan, dan jumlah personil untuk peningkatan TLHP. Dari hasil penelitian menunjukkan bahwa kualitas SDM sudah cukup memadai. Namun perlunya pemahaman tentang cara menindaklanjuti rekomendasi hasil pemeriksaan. Hambatan SDM bagi tim teknis, yaitu mengalami kesulitan dalam rangka pemetaan data seringkali tidak sesuai dengan data yang dibuat tim BPK karena regulasi atau mekanisme yang dinamis. Hambatan lainnya juga terdapat pada jumlah personil yang dilibatkan dalam pelaksanaan TLHP masih kurang dan hanya bertumpuk pada satu orang.

Lina Anatan dan Lena Ellitan (2007) menyatakan bahwa strategi bisnis akan berhasil jika organisasi mampu mengelola dan meningkatkan kualitas SDM (SDM berbasis kompetensi). Peningkatan kualitas SDM melalui peningkatan pengetahuan, keterampilan, dan kemampuan. Sehingga SDM yang terlibat dalam proses atau kegiatan perusahaan merupakan SDM berbasis pengetahuan yang memiliki keterampilan dan keahlian.

Upaya peningkatan SDM akan dilakukan oleh pimpinan Inspektorat. Upaya tersebut, yaitu memberikan kesempatan untuk melakukan konsultasi ke BPK, mengikuti Bimtek di BPK tentang proses pemantauan tindak lanjut melalui aplikasi online, menyekolahkan ke luar daerah, mengundang narasumber untuk melakukan Bimtek di kantor sendiri, mengikuti sosialisasi tentang tindak lanjut yang dilakukan BPK, dan mengikuti rapat tindak lanjut rekonsiliasi data.

Pengembangan pegawai merupakan aktivitas memelihara dan meningkatkan kompetensi pegawai guna mencapai efektivitas organisasi. Pengembangan pegawai dapat diwujudkan melalui pengembangan karir, serta pendidikan dan pelatihan (Suwatno dan Priansa, 2016).

\section{Motivasi dan Kepuasan Kerja}

Motivasi dan kepuasan kerja yang diberikan pimpinan dari hasil wawancara menunjukkan bahwa pimpinan selalu mendorong pegawai melakukan pekerjaan, memberikan penghargaan, dan kesempatan sehingga pegawai benar-benar menunjukkan keterlibatan dan usaha-usaha dalam peningkatan TLHP BPK RI.

Menurut Sagir (1985) dalam Siswanto (2012) elemen penggerak motivasi seseorang meliputi, kinerja (achievement), penghargaan (recognition), tantangan (challenge), tanggung jawab (responsibility), pengembangan (development), keterlibatan (involvement), dan kesempatan (opportunity).

Dari hasil penelitian informan menjelaskan bahwa motivasi atas kesempatan diberikan pimpinan kepada pegawai berprestasi berupa melaksanakan kegiatan di luar daerah, dan mengikuti Diklat dalam rangka peningkatan kemampuan. Motivasi juga diberikan pimpinan melalui pemberian pekerjaan kepada pegawai untuk melaksanakan tugas khususnya tim TLHP BPK RI bebas berkreasi memberikan hasil yang maksimal, menciptakan situasi kerja yang mantap, dan tim harus bekerja dalam sistem. Selain itu juga motivasi yang diberikan 
pimpinan kepada pegawai adalah pemberian penghargaan kepada pegawai yang berprestasi kerja yang baik, mempunyai integritas yang tinggi, dan tanggung jawab atas tugas yang diberikan. Pemberian penghargaan yang diberikan berupa penugasan ke luar daerah, dan senantiasa dilibatkan dalam tugas sehari-hari maupun tugas pemeriksaan.

Motivasi atas kepuasan kerja diberikan kepada pegawai berupa honor beban kerja, pemberian honorarium Majelis TPTGR, dan pemberian fasilitas pendukung. Imbalan yang diberikan ini merupakan bentuk motivasi pimpinan kepada pegawai atas prestasi kerja yang diberikan untuk pencapaian tujuan organisasi. Dengan pemberian motivasi ini diharapkan dapat menimbulkan kepuasan kerja yang tinggi bagi pegawai untuk meningkatkan pelaksanaan TLHP BPK RI.

\section{Komitmen}

Pandangan komitmen dilihat dari komitmen pimpinan, komitmen pegawai sekaligus tim teknis TLHP dalam mencapai efisiensi, efektivitas, dan akuntabilitas jalannya organisasi serta komitmen dari pemerintah daerah akan peran dan fungsi Inspektorat dalam urusan penyelenggaraan pemerintahan di Kabupaten Kepulauan Talaud.

Menurut Inspektur komitmen pimpinan adalah pimpinan yang mampu melakukan program kerja, sasaran dan tujuan ditetapkan dengan baik mengedepankan efisiensi dan akuntabilitas terhadap pelaksanaan tugas. Bagi pegawai dibawahnya komitmen dari pimpinan adalah selalu mengefektifkan semua kegiatan sesuai dengan anggaran yang tersedia, harus memprioritaskan tindak lanjut yang sulit diselesaikan, meningkatkan tindak lanjut, memberikan motivasi untuk segera menuntaskan temuan-temuan, memperhitungkan biaya yang dikeluarkan dengan hasil yang dicapai, melibatkan peran masing-masing pegawai, dan bagaimana mencapai target khususnya TLHP BPK RI.

Seperti yang disebutkan Locke dan Latham (2002) dalam Teori Penetapan Tujuan (Goal Setting Theory) bahwa tiga moderator yang menunjukkan tujuan keberhasilan, yaitu : (1) pentingnya hasil yang diharapkan dari pencapaian tujuan; (2) keyakinan seseorang bahwa mereka mampu untuk mencapai tujuan; dan (3) komitmen kepada orang lain, janji atau keterlibatan orang lain dapat meningkatkan komitmen.

Komitmen pemerintah daerah akan peran dan fungsi Inspektorat Kabupaten Kepulauan Talaud dalam urusan penyelenggaraan pemerintahan disampaian pemerintah daerah tidak hanya secara lisan, tapi ada pernyataan tertulis yang disebut sebagai Audit Charter atau perjanjian kinerja antara pemerintah daerah dan Inspektorat.

\section{Kepemimpinan}

Gambaran tentang dukungan maupun keterlibatan pimpinan dalam pelaksanaan TLHP BPK RI dari hasil penelitian diperoleh bahwa pimpinan senantiasa memperhatikan target waktu, anggaran, capaian, dan proses yang dilakukan. Selalu mengingatkan kepada tim jangan lengah, mendorong, memberikan tanggung jawab kepada sub bagian evaluasi dan pelaporan, memberikan petunjuk, dan memberikan pujian. Keterlibatan pimpinan berupa pembagian tugas secara merata dalam tim, melakukan rapat, bekerjasama dengan tim kerja, dan selalu bersama dalam proses penyelesaian tindak lanjut.

McShane dan Glinow (2010) menyatakan kepemimpinan adalah tentang mempengaruhi, memotivasi, dan memungkinkan orang lain memberikan kontribusi ke arah efektivitas dan keberhasilan organisasi di mana mereka menjadi anggotanya. Kepemimpinan adalah proses mempengaruhi dan mendukung orang lain untuk bekerja secara antusias menuju pada pencapaian sasaran (Newstrom, 2011).

\section{Pengkomunikasian dan Koordinasi}


Menurut semua informan bahwa komunikasi selalu dilakukan baik secara lisan maupun tertulis. Secara lisan, yaitu menginformasikan, menjelaskan perihal temuan yang dimaksud, dan membuat kesepakatan untuk penyelesaian dalam rapat maupun di waktuwaktu senggang. Sedangkan secara tertulis, yaitu menyurat kepada SKPD terkait temuan. Koordinasi juga dilakukan dengan pimpinan, sesama anggota tim, dan koordinasi dengan BPK maupun BPKP perihal tindak lanjut.

Sebagaimana menurut Robbins dan Judge (2011) komunikasi interpersonal dapat dilakukan melalui oral communication, written communication, atau nonverbal communication. Oral communication atau komunikasi lisan merupakan sarana utama untuk menyampaikan pesan berupa pidato, dan diskusi individual atau kelompok. Written communication atau komunikasi tertulis dilakukan melalui memo, surat, peringatan pada papan pengumuman, dan cara lain yang disampaikan melalui kata tertulis atau simbol. Nonverbal communication, ujudnya dapat berupa pandangan sekilas, tatapan, senyuman, mengerutkan dahi, atau gerakan tubuh.

\section{Standar Operasional Prosedur}

Pelaksanaan TLHP BPK RI menurut informan telah dilakukan sesuai SOP TLHP. Namun SOP TLHP BPK RI ini baru disesuaikan, belum dipublikasi atau belum disampaikan kepada anggota tim SOP. Selain itu terdapat juga hambatan dalam penerapan SOP tentang masalah administrasi, yaitu kelengkapan data. Hal ini sering menghambat proses tindak lanjut, sehingga tahapan-tahapan dalam SOP tersebut seringkali tidak dilaksanakan atau dilangkahi oleh tim teknis SOP TLHP BPK RI.

SOP atau SPO menurut Tambunan (2013) merupakan suatu pedoman yang berisikan prosedur-prosedur operasional standar yang ada didalam suatu organisasi yang digunakan oleh organisasi untuk memastikan bahwa setiap keputusan, langkah atau tindakan dan penggunaan fasilitas pemrosesan yang dilaksanakan oleh orang-orang didalam suatu organisasi, telah berjalan secara efektif, konsisten, standar dan sistematis.

Proses tindak lanjut belum sepenuhnya dilakukan berdasarkan prosedur yang tertuang dalam SOP TLHP BPK RI. Hal ini disebabkan berbagai hambatan di SKPD menyangkut administrasi kelengkapan data yang diperlukan tim teknis Inspektorat, sehingga ada tahapan-tahapan dalam SOP yang dilangkahi untuk mempercepat penyelesaian TLHP.

\section{Monitoring dan Evaluasi}

Pelaksanaan monitoring dan evaluasi terhadap TLHP BPK RI selalu dilakukan hampir setiap bulan. Disamping itu juga kegiatan monitoring dilakukan oleh BPK Perwakilan Propinsi Sulawesi Utara dalam rangka pemantauan sejauh mana capaian pelaksanaan tindak lanjut dan rekonsiliasi data TLHP BPK RI di Kabupaten Kepulauan Talaud. Setelah kegiatan monitoring dilakukan evaluasi untuk langkah perbaikan dan pengambilan keputusan atas progress, hambatan, dan upaya yang dilakukan terkait pelaksanaan tindak lanjut.

Menurut Burhanuddin dalam Arini (2014) menyebutkan monitoring adalah proses rutin pengumpulan data dan pengukuran kemajuan atas objektif program atau memantau perubahan yang fokus pada proses dan keluaran. Monitoring melibatkan perhitungan atas apa yang kita lakukan dan pengamatan atas kualitas dari layanan yang kita berikan. Evaluasi adalah suatu proses sistematik untuk mengetahui tingkat keberhasilan suatu program. Proses evaluasi bukan sekedar untuk mengukur sejauh mana tujuan tercapai, tetapi digunakan untuk membuat keputusan.

\section{Penutup}


Kesimpulan penelitian adalah pelaksanaan TLHP BPK RI pada kenyataannya masih mengalami berbagai hambatan dalam proses penyelesaian tindak lanjut. Hambatan tersebut berakibat pada permasalahan tindak lanjut belum sesuai rekomendasi, rekomendasi yang belum ditindaklanjuti, temuan yang sulit ditindaklanjuti, dan keterlambatan penyelesaian tindak lanjut. Selain itu juga didapati hambatan SDM tim teknis, dan SOP TLHP BPK RI.

Untuk mengatasi berbagai hambatan tersebut, akan dilakukan upaya-upaya untuk peningkatan TLHP BPK RI, dan peningkatan sumber daya manusia.

Saran yang dapat diberikan adalah :

1. Mempercepat penyelesaian tindak lanjut dengan memaksimalkan sumber daya dan fasilitas yang ada.

2. Berupaya mengatasi hambatan-hambatan yang menghambat keberhasilan pelaksanaan TLHP dengan meningkatkan koordinasi yang baik dengan pihak terkait atau penanggung jawab temuan.

3. Meningkatkan pengetahuan, keterampil-an, dan kemampuan tim teknis SOP TLHP BPK RI dengan mengikutsertakan dalam pelatihan dan bimbingan teknis terkait penanganan tindak lanjut.

4. Menambah personil atau pegawai yang secara khusus terlibat dalam penanganan tindak lanjut.

5. Mensosialisasikan SOP TLHP BPK RI yang telah dibuat kepada seluruh tim teknis.

6. Perlu dibuatkan alur kerja pelaksanaan tindak lanjut untuk masing-masing wilayah keIrbanan dan Sub Bagian Evaluasi dan Pelaporan.

\section{Daftar Pustaka}

Akmal. 2006. Pemeriksaan Intern (Internal Audit). PT. INDEKS Kelompok Gramedia. Jakarta.

Bungin Burhan. 2007. Penelitian Kualitatif Komunikasi, Ekonomi, Kebijakan Publik, dan IImu Sosial. Edisi Kedua. Kencana Prenada Media Group. Jakarta.

Kaplan S. Robert and David P. Norton. 1996. The Balanced Scorecard Translating Strategy into Action. Edisi Satu. United States of America. Harvard Business School Press.

Lina Anatan dan Lena Ellitan. 2007. Manajemen Sumber Daya Manusia Dalam Bisnis Modern. CV. Alfabeta. Bandung.

Locke, E. A., \& Latham, G. P. (2002). Building a practically useful theory of goal setting and task motivation a 35-year odyssey. American Psychologist.

Newstrom, John W. 2011. Organizational Behavior, Human Behavior at Work. McGraw-Hill Companies. New York.

Robbins, Stephen P. and Timothy A. Judge. 2011. Organizational Behavior. Pearson Education. New Jersey.

Siswanto. 2012. Pengantar Manajemen. Cetakan ke Delapan. PT Bumi Aksara. Jakarta.

Sugiyono. 2015. Metode Penelitian Manajemen. Cetakan Keempat. CV. Alfabeta. Bandung.

Suwatno H dan Priansa D. J. 2016. Manajemen SDM dalam Organisasi Publik dan Bisnis. Alfabeta. Bandung.

Tugiman Hiro. 1997. Standar Profesional Audit Internal. Kanisius. Yogyakarta.

Usman H. 2013. Manajemen Teori, Praktik, dan Riset Pendidikan. Edisi Ke Empat. PT Bumi Aksara. Jakarta.

Ikhtisar Hasil Pemeriksaan Semester I Tahun 2016. Badan Pemeriksa Keuangan RI. Jakarta.

Modul Program Pendidikan Non Gelar Auditor. 2007. Manajemen Fungsi Audit Internal Sektor Publik. Sekolah Tinggi Akuntansi Negara. YPIA. Tangerang.

Peraturan Badan Pemeriksa Keuangan Republik Indonesia Nomor 2 Tahun 2010 Tentang Pemantauan Pelaksanaan Tindak Lanjut Rekomendasi Hasil Pemeriksaan Badan Pemeriksa Keuangan. 
Arini I Gusti Agung Ayu Kusuma. 2014. http://lib.ui.ac.id. Tesis Analisis Peran Manajemen Dalam Tindak Lanjut Hasil Pemeriksaan Oleh Satuan Pemeriksa Intern di RSUP Sanglah. Universitas Indonesia. Depok.

Hartono Tri. 2006. http://eprints.undip.ac.id. Tesis Evaluasi Penyelesaian Tindak Lanjut Temuan Audit Sebagai Unsur Penilaian Kinerja Manajemen Kantor Cabang (Studi Kasus Pada Bank BTPN). Universitas Diponegoro. Semarang. 